\title{
Disability Mainstreaming Program: In Search of Disability Inclusion in Islamic Higher Education
}

\author{
Siti Napsiyah \\ Social Welfare Study Program \\ Syarif Hidayatullah \\ State Islamic University (UIN) \\ Jakarta, Indonesia \\ siti.napsiyah@uinjkt.ac.id.
}

\begin{abstract}
This paper aims to discuss the possibility of adapting Gender Mainstreaming Program years ago conducted by government, non-government organization and educational institution which has shown great achievement for women equal right. Thus, this study tries to answer the following questions: How should Gender Mainstreaming Program can be adapted as a strategy for Disability Mainstreaming Program in Islamic Higher Education? What are the strategic programs able to support the regulation of the Ministry of National Education of Republic of Indonesia Number 70 of 2009? What is the role of Islamic principles in the promotion of disability inclusive campus?

This study uses a qualitative research method. A review of selected literature and data analysis on policy on inclusive education, gender mainstreaming program, social work, and Islamic values on disability. Data collection method of the study uses observation, interview, and documentation. And to get research validity this study uses triangulation as well as peer discussion.
\end{abstract}

The result of this study confirms that Disability Mainstreaming Program should be a simultaneous, comprehensive, and coordinated movement in all government institutions and nongovernmental organization in Indonesia in order to achieve an inclusive society. It is a systemic integration strategy of disability inclusion in all system and structures, including policies, programs, process, and projects, culture, organization and actions that prioritize disability inclusion. The principles role not limited only in the promotion of inclusive curricula, but firstly should build a center for the study and services for people with disabilities and special need. Last, this study also concludes that social work perspective sees disability mainstreaming is a strategy to achieve equality and justice through the planning and implementation of disability inclusion in educational institutions and community as a whole.

Key Words: Inclusive education, disability mainstreaming program, social exclusion, discrimination

\section{INTRODUCTION}

The problem of social exclusion and discrimination towards persons with disabilities (PWDs) still become serious issue in Indonesian Higher Education system. The Indonesian Central Bureau of Statistics reported that in 2012 National Socioeconomic Survey, number of Persons with disabilities in Indonesia is $2.45 \%$ of the total population. The survey indicated that the level of education related to the rates of disability. The low level of education related to high rate of disability.[1]

Soleh argues one of serious problems faced by Higher Education is accessibility [2]. However, since the inclusive education policy in Indonesia has been implemented, more and more universities are striving to realize their campus as an inclusive university. They struggle to provide better accessibility for the disabled students by building facilities and infrastructures. This is due to the recognition that disabled students have more barriers to social and academic participation. The barriers related to accessibility, acceptance, and facilities. Not to mention the problem of discrimination that is always inherent in the lives of persons with disabilities. Discrimination is become serious issue for the disabled persons. The vulnerability of people with disabilities is not only in the wider community, but also in educational institutions. The example of disabled vulnerability is bullying-based on physical impairment. Bullying becomes part of discrimination towards People with Disabilities. The United Nation Convention on The Right of People with Disabilities (UNCRPD) defines discrimination on the basis of disability as any distinction, exclusion or restriction on the basis of disability which has the purpose or effect of impairing or nullifying the recognition, enjoyment or exercise, on an equal basis with others, of all human rights and fundamental freedoms in the political, economic, social, cultural, civil or any other field. It includes all forms of discrimination, including denial of reasonable accommodation [3].

There are theoretical, legal, as well as religious foundation validate the importance of disability inclusion and anti-discrimination against people with disabilities. Indonesia has not only ratified the United Nation Convention on the Rights of Persons with Disabilities (UNCRPD), but also has established the Act No. 82016 about Disability Right and UU No. 202003 about inclusive education. Similarly, Islam is the most inclusive of people with disabilities. In Islam, as reported by Hasnain disabilities considered normal aspects of the human as stated in the Holy Qur'an evidenced by the prescriptions for how and to what extent individuals 
with disabilities can and should participate in religious and secular life [4].

According to Hasnain, et.al.(2008) in Islam, a person's worth is based not on any physical or material characteristics but on piety [4].

Piety includes both faith in the tenets of Islam and a genuine attempt to adhere to Islam's obligations to the best of one's ability. It is also stated that the value of the individual's faith and obedience to Allah rather than their physical, intellectual and mental abilities. In addition, article 8 of UNCRPD mandates to raise awareness throughout society, including at the family level, regarding persons with disabilities, and to foster respect for the rights and dignity of persons with disabilities; to combat stereotypes, prejudices and harmful practices relating to persons with disabilities, including those based on sex and age, in all areas of life.

However, there are number of inequalities and social injustices in the life experience of people with disabilities in society and university. It is unfortunate, because education plays an important role as a process for fighting discrimination, promoting social justice, and overcoming poverty has been undisputable (Caillods and Hallak 2004; Raffo \& al 2009). So then, it is clear that to fight against discrimination should be started from education.

This paper aims to discuss the strategy, approach and structure of disability mainstreaming program at the university level adapted from JICA's Gender Mainstreaming Program. JICA launched a new vision for promoting "Inclusive and Dynamic Development" in 2008 [5]. Gender mainstreaming explicitly underpins the idea of "inclusive development", which aims to benefit all people, regardless of ethnicity, religion, gender, or age [5].

Previous research confirms Gender and HIV/AIDS mainstreaming have both been largerly accepted as essential frameworks in international development programming, and there is much to be learned from these experiences with mainstreaming. The literature on both HIV/AIDS and gender mainstreaming stresses the importance of concrete, measurable actions within specific sectors and contexts, to ensure that mainstreaming efforts are actually implemented. The need of massive, organized, integrated and interconnected program should be conducted as massive as gender and HIV/AIDS issue. The convention on the Rights of Persons with Disabilities offers an ideal opportunity to consolidate disability-related activities, and to develop policies and structures that ensure that persons with disabilities are mainstreamed within the United Nations System. Lessons learned from gender and HIV/AIDS mainstreaming can provide valuable guidance, and there are an increasing number of tools to inform and guide this process, which when coupled with strong political will can lead to significant. In addition, Regional Preparatory International Conference in Bali, Indonesia, held on May 2931, 2009 recognized that some children are still discriminated by their physical disabilities, mental retarded ness, and being having HIV/AIDS [6].
This paper discusses the idea of Disability Mainstreaming Program in order to create better life for the disabled people. Mainstreaming means a broad-reaching goal, the actions required to achieve it consist of measurable concrete steps taken by individuals such as Government ministers, departmental heads, directors of organizations, and director of higher education, stakeholders, and community [7]. Disability issues, is indeed need to be incorporated into organizational policy and practice in the form of job descriptions, mission and vision statements, and budget allocations.

This paper offers strategic steps and approaches for the universities to implement the Disability Mainstreaming Program in society. According to Bausela, as stated in Morgado, Cortes-Vega, Lopez-Gavira, Alvarez and Morina (2016),[8] "universities are among the most discriminating institutions, both in terms access for certain students and in facilitating their continuity in Higher Education so that they do not abandon their educational career prior to earning a degree [7]. This paper seeks to answer the recommendation of world country report of WHO (2011) on the importance of enable access to all mainstream systems and services.

\section{METHODS}

This study uses a qualitative research method. A review of selected literature and data analysis on policy on inclusive education, gender mainstreaming program, social work, and Islamic values on disability. Data collection method of the study uses observation, interview, and documentation. And to get research validity this study uses triangulation as well as peer discussion.

Literature reviews on mainstreaming program. Selected topic on mainstreaming disability in Indonesia as well as documents related to gender mainstreaming program. Data collection conducted by searching the issue on disability mainstreaming program by using key words, authors, institution, resource person ideas, disability events. The source of data and information refer to documents, journals, country reports, previous research, and the like. Whereas the interview is conducted to the purposive and selected resource persons represented from student with disabilities and the university managers.

TABLE 1:

\begin{tabular}{|l|l|l|l|}
\multicolumn{5}{|c|}{ TABLE 1: } \\
\hline NO. & Data/information & Resource person & Other \\
\hline 1. & $\begin{array}{l}\text { Accessibility, assistive } \\
\text { technology, curricula, } \\
\text { class design, barrier in } \\
\text { learning, social } \\
\text { participation }\end{array}$ & $\begin{array}{l}\text { Student with } \\
\text { disabilities }\end{array}$ & 2 \\
\hline 2. & $\begin{array}{l}\text { Assistive technology, } \\
\text { course material, teaching } \\
\text { methods, class } \\
\text { assignment, inclusive }\end{array}$ & $\begin{array}{l}\text { Lectures } \\
\text { Policy on disabled } \\
\text { education, } \\
\text { student services }\end{array}$ & 2 \\
\hline 3. & $\begin{array}{l}\text { Gender mainstreaming } \\
\text { program at State Islamic } \\
\text { University }\end{array}$ & $\begin{array}{l}\text { Head of the } \\
\text { Center of Women } \\
\text { Studies }\end{array}$ & 1 \\
\hline 4. & \multicolumn{2}{|c|}{} & 3 \\
\hline
\end{tabular}




\section{RESULT AND DISCUSSION DISABILITY}

There are many terminologies of disability existed in society and varies depend on the context of society and history. In Indonesia, disability related term that widely used in society are: kelainan (abnormal), tuna (deficit/loss), and cacat (defect/invalid). Those terminologies at some points invite stigma and are demeaning to people with impairments. But Then, term of penyandang disabilitas (people who have disability) becomes more popular as the term of difable (people who have different ability). It is proposed by nongovernment organization (NGO) in order to minimize stigma and discrimination among disabled persons in society [9].

Disability conventionally understood as the condition of someone who is not able to use a part or parts of her/his body and depicted primarily in terms of its being an individual tragedy. But in the Equality Act (2010) a person has a disability if: (1) they have a physical or mental impairment; (2) the impairment has a substantial and longterm adverse effect on their ability to perform normal day-today activities. According to Harris and White (2003) person has disability if they have a physical or mental impairment. The Impairment itself has substantial and long-term adverse effect on their ability to perform normal day-to-day activities [10].

Callard [11] refers the concept of disability to the UNCRPD's explanation that disability as an evolving concept and that disability results from the interaction between persons with impairments and attitudinal and environmental barriers that hinders their full and effective participation in society on an equal basis with others. Whereas who includes as persons with disabilities are those who have long-term physical, mental, intellectual or sensory impairments which in interaction with various barriers may hinder their full and effective in society on an equal basis with others [3]. In addition, according to World Health Organization (WHO) disability "is an umbrella term, covering impairments, activity limitations, and participation restrictions. An impairment is a problem in body function or structure; an activity limitation is difficulty encountered by an individual in executing a task or action; while participation restriction is a experienced by an individual in involvement in life situations. Disability is thus not just a health problem. It is a complex phenomenon, reflecting the interaction between features of a person's body and features of the society in which he or she lives" [12].

The Encyclopedia of Social Work explains disability into three categories: Moral, medical, and social models. The moral and medical models define disability as pathological individual characteristic. In contrast, the social model defines disability as a diverse attribute in society [13]. With the emergence of the social model of disability, societal conceptualizations of disability are changing. World Health Organization (WHO) (1980) published The International Classification of Impairments, Disabilities, and Health (ICD) that classified disability, impairment, and handicaps as internal problems. Impairment: Any Loss or abnormality of psychological, physiological, or anatomical structure or function; Disability: Any Restriction or lack (resulting from an impairment) of ability to perform an activity in the manner or within the range considered normal for human being; Handicap: A disadvantage for a given individual, resulting from an impairment or disability, that limits or prevents the fulfillment of a role that is normal, depending on age, sex, social, and cultural factors, for that individual [13].

Figure 1:

Medical Model of Disability and Social Model

\begin{tabular}{|l|l|}
\hline Medical Model of Disability & Social/Interactional Model \\
\hline $\begin{array}{l}\text { Disability is a deficiency or } \\
\text { abnormality }\end{array}$ & Disability is a difference \\
\hline Being disabled is negative & Being disabled, in itself, is neutral \\
\hline Disability resides in the individual & $\begin{array}{l}\text { Disability derives from interaction between } \\
\text { individual and society }\end{array}$ \\
\hline $\begin{array}{l}\text { The remedy for disability-related } \\
\text { problems is cure or normalization of } \\
\text { the individual }\end{array}$ & $\begin{array}{l}\text { The remedy for disability-related problems is } \\
\text { a change in the interaction between the } \\
\text { individual and society }\end{array}$ \\
\hline $\begin{array}{l}\text { The agent of remedy is the } \\
\text { professional who affects the } \\
\text { arrangements between the } \\
\text { individual and society }\end{array}$ & $\begin{array}{l}\text { The agent of remedy can be the individual, } \\
\text { an advocate, or anyone who affects the } \\
\text { arrangements between the individual and } \\
\text { society. }\end{array}$ \\
\hline
\end{tabular}

Source : Carol J. Gill, Chicago of Disability Research.

Figure 2:

Evolution on Disability Terminology in Indonesian National and Local Legislation

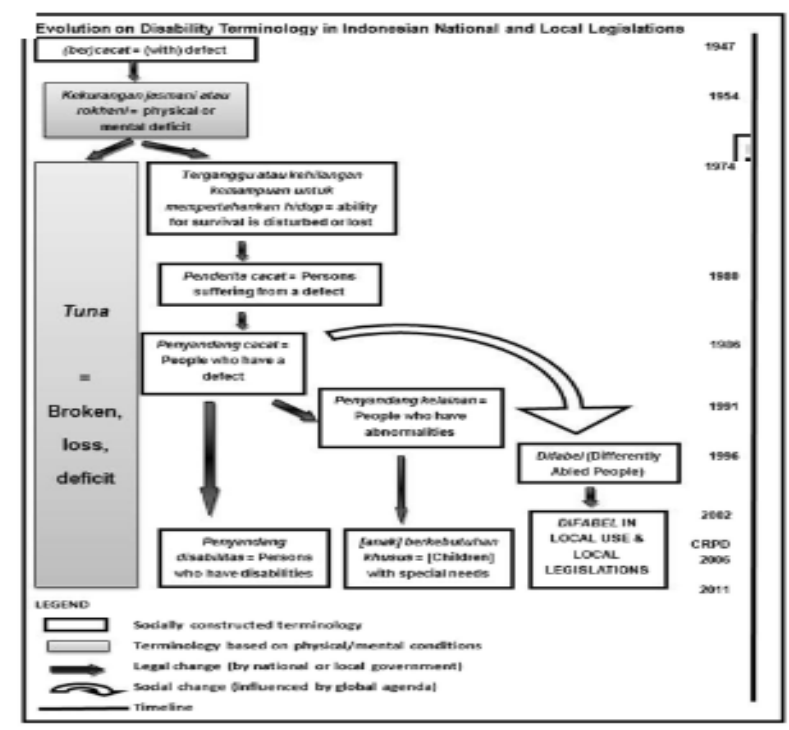

\section{A. $\quad$ Student with Disabilities Barriers}

Below is the description and data information from the perception of first year university students with disability which confirm the strengths and weakness of accessibility in 
UIN Jakarta. There are only two (2) first year student of UIN Jakarta considered as "disabled student" for now. Both consist of one (1) male and one female (1). Both are represented from the applied sciences and social sciences. The lack number of disabled first year student at UIN Jakarta invites many questions such as why parent do not "trust" UIN Jakarta for their disabled student? why does UIN Jakarta less attracted for the disabled to study? Why does disabled students have more barriers in learning? and the like.

Data confirms disabled students do not have special adjustment of disability services since senior high school. Both disabled student considered to have Agenesia Corpus Collosum (unperfect bridge between the right and left brain). There is no varies of impairment categories. There is no impairment categorization as listed in the disability module: language impairment, aural impairment, ocular impairment, skeletal impairment, disfiguring impairment, and sensory impairment. As it is clearly stated in the target groups of the needs analysis of this project: "Disability is an impairment that may be cognitive, developmental, intellectual, mental, physical, sensory, or some combination of these. It substantially affects a person's life activities and may be present from birth or occur during a person's lifetime". Thus, again for the UIN Jakarta case, the factor is due to the lack number of disabled student at UIN Jakarta. The selected data indicates the existing number of disabled student. The University does not have a specific student admission path for the disabled. Along with the establishment of a Disability Center in UIN Jakarta, in the near future, we hope, there will be more varies of impairment categories of disabled student.

Data ( $1^{\text {st }}$ year student) informs inaccessible classroom lay out and teaching method for the disabled student. Fortunately, as they do not have any physical impairment, so far and for now, inaccessible facilities such as class room, library, toilet and other campus facilities, not their primary barriers. But imagine, if there is disabled student who has physical impairment such as mechanical impairment of limb, spastic paralysis of more than one limb, other paralysis of limb, and other motor impairment of limb.

Data ( $1^{\text {st }}$ year student) informs mostly the answer is number 4 (four) means "disagree" to answer such the following questions: "to what extent you agree/disagree on the following statements: There is a specific admission process for the entrance of the students with disability in your HEI"?; "There are various presentation methods and tools (written and verbal) being used by academics, in order to make pedagogical material available and accessible to all students"?; "Classroom space is organized so that every student has the space he/she requires, regardless of size, posture, and mobility"?; The classrooms are easily accessible to students with disabilities.

In addition, when they have asked the question about assistive technology (AT): "Does your university make use of AT?" and "Do academics consider assistive technology when planning and anticipating for students' individual learning needs?" their answers are similar" "No". The university has not provided assistive technology yet for learning-teaching activities. Lectures do not have applied assistive technology to support their method in order to help the disabled student. So, it is clear, that the challenge of UIN Jakarta is to ensure some inclusive and accessible curricula as well as learning environment that values student from diverse background (of impairment and special needs). The university manager (Rector and vices rector), staff member, employer and lecturer should recognize that inclusive learning culture is one that eliminates barriers of students with disabilities to full participation by providing an environment that cultivates respect, equity and positive recognition of differences.

Figure 3: The Availability of Assistive Technology at Syarif Hidayatullah State Islamic University

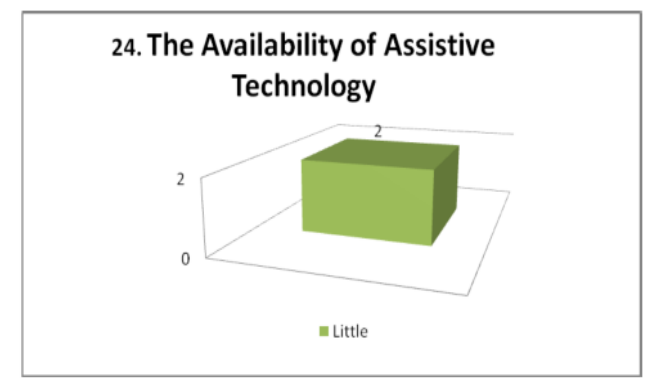

Since the change of disability data from health indicator become social welfare indicator, the issue of disability is considered as a social sector problem. According to UU No. 11 of 2009 on Social Welfare and Social Ministry Decree No. 82/HUK/2005 on the Duties and Working Arrangement of the Ministry of Social Affairs states that the focal point in handling the problem of persons with disabilities in Indonesia is the Ministry of Social RI. According to Irwanto (2010) the task is more directed at the effort service and social rehabilitation, namely the process of re-functionalization and development to enable persons with disabilities to perform their social functions reasonably in public life [14].

On the other hand, World Health Organization (WHO)[12] reports on disabling barriers as follows:

1. Inadequate policies and standard

2. Negative attitude

3. Lack of provision of services

4. Problems with service delivery

5. Inadequate funding

6. Lack of accessibility

7. Lac of consultation and involvement

8. Lack of data and evidence

\section{B. Disability Mainstreaming Program}

Disability Mainstreaming at the Higher Education System is a strategy for achieving equality for persons including students with disabilities. According to General Assembly Resolution (2006) Governments, international organizations, organizations of persons with disabilities and other civil society organizations are working with renewed 
vigour towards the goal of equality following the adoption of the Convention on the Rights of Persons with Disabilities, in December 2006 (General Assembly Resolution 61/106, annex 1) [7].

The concept of gender mainstreaming was defined in July 1997, by the Economic and Social Council in the agreed conclusions 1997/2 on mainstreaming a gender perspective into all policies and programmes of the United Nations system. The Commission for Social Development (2008) explains gender mainstreaming as the process of assessing the implications for women and men of any planned action, including legislation, policies or programmes, in any area and at all levels. It is a strategy for making the concerns and experiences of women as well as of men an integral part of the design, implementation, monitoring and evaluation of policies and programmes in all political, economic and societal spheres, so that women and men benefit equally, and inequality is not perpetuated. The ultimate goal of mainstreaming is to achieve gender equality. The process of disability mainstreaming in the development agenda may be viewed in a similar manner [15].

In reference to above definition regarding gender mainstreaming, it clearly explains the term of mainstreaming which involves building disability into existing agendas, frameworks, and processes. Similarly, The Voluntary Service Overseas (VSO) Indonesia defines mainstreaming as the process of engaging in a structured way with an issue as an organization, at workplace, program and policy levels, in order to address, and avoid increasing, the negative effects of that issue [16].

The working group discussion on disability mainstreaming recommends to do disability mainstreaming at all stages of action is very fundamental, from early design and preparation to monitoring and evaluation [17]. Undoubtable, that disability mainstreaming as process and effort to address social exclusion among disabled persons in all aspect of life as well as to encourage them to the better and equal participation in society.

\section{The Mainstreaming Model}

Below is proposed disability mainstreaming model which I adapt from HIV AIDS Mainstreaming Model developed by VSO (2006):[18]

- Organizational commitment: In the case of State Islamic University (UIN) Jakarta, the Center for Special Need (CSSN) should socialize disability awareness which imbedded in the entire of UIN organization's values and activities, including inclusive curricula and disabled friendly campus.

- Sensitization: It is the process which all parties of UIN Jakarta and its stakeholder to commit and to engage with disability issues. The essence of sensitization is about individual participation to the organizational commitment to raise social awareness of the right of disabled persons.

- Workplace mainstreaming: It is the effort of the institution (UIN Jakarta) to formulate and implement policies on disability mainstreaming as well as to create inclusive environment, equitable and non-discriminatory on the basis of person's physical disabilities.

- Policy mainstreaming: It is the effort of addressing wider policy and institutional barriers that exclude student, academicians and staff member from equal participation in the campus life.

Figure 4:

The VSO Mainstreaming Model

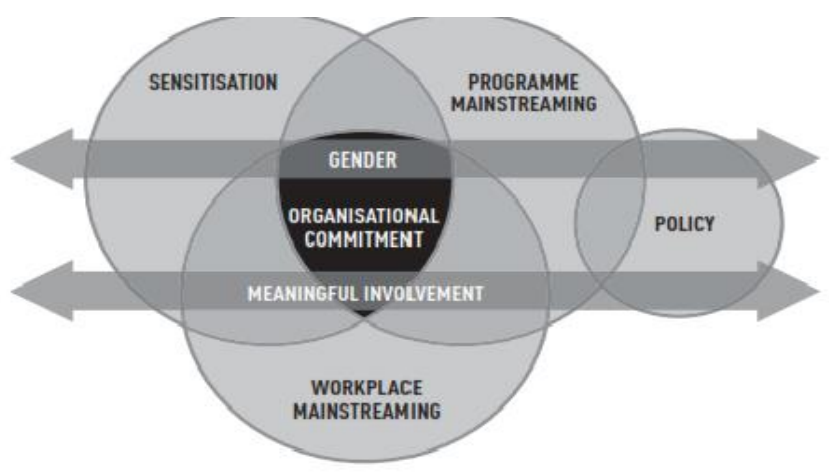

Below is the proposal design of Disability Mainstreaming in the Higher Education System. It aims to support the University (UIN Jakarta) capacity, policy and institutional development for disability mainstreaming.

1. Disability Equality Program

a. Institutional capacity building of the State Islamic University (UIN) Jakarta: Training of the Trainer (ToT) for Lectures and Volunteers of Disabled Persons.

b. Promoting Disability Equality and Social Inclusion in both academic and social life of disabled students

2. Project Targeted Disabled Student

a. Strengthening the Stigmatized Disabled Student (Achievement Motivation Training on Self-Concept and Self-Identity)

b. Empowering Disabled student (Equal opportunity for social and academic participation among disabled students)

3. Disability Integrated Project

a. Project on disability and social inclusion

b. Project on Loan for the Poorest Disabled Student

c. Project on the promotion of Social Participation of Person with Disabilities (PWDs)

d. Training Program for the University Manager, Lecturer, and Staff Member 

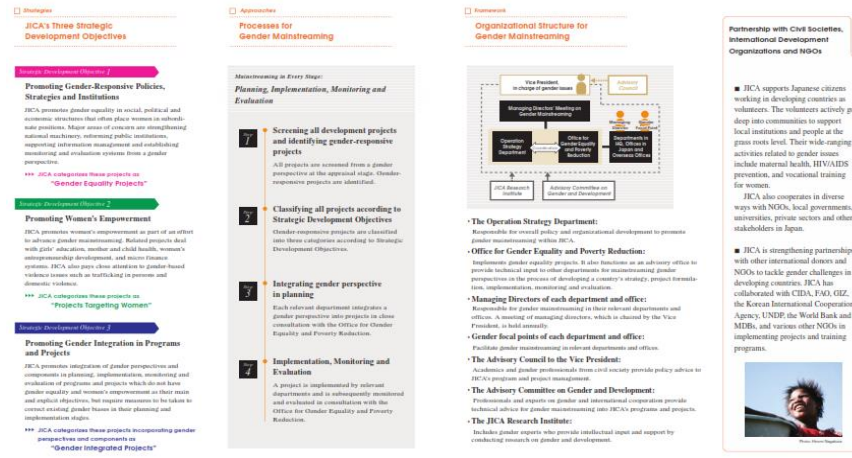

Based on JICA's[5] strategy, approach, and framework for gender equality and women empowerment as illustrated in the above figure, below is the proposed UIN's strategy, approach and framework for disability equality and social inclusion.

a. Strategies:

1. Promoting Disability -Responsive Policies, Strategies and Institution

2. Promoting Disabled Student Empowerment

3. Promoting Disability Integration in Program and Project

b. Approaches (process)

1. Screening all development projects and identifying disability responsive project

2. Classifying all projects according to strategic development objectives

3. Integrating disability perspective in planning

4. Implementation, monitoring, and evaluation

c. Framework (organizational structure for disability mainstreaming)

To sum up, mainstreaming must be conducted in every stage: $\left(1^{\text {st }}\right)$ screening all development projects and identifying disability responsive projects; $\left(2^{\text {nd }}\right)$ Classifying all projects according to strategic development objective; $\left(3^{\text {rd }}\right)$ integrating disability perspective in planning; $\left(4^{\text {th }}\right)$ implementation, monitoring, and evaluation.

\section{Inclusive Education in Indonesia}

Philosophical foundation for inclusive education in Indonesia is "Bhineka Tunggal Ika" (Unity in Diversity). Disability is part of diversity same as race, culture, language, and religion. In addition, below are legal foundations for the implementation of disability mainstreaming effort in Indonesia:

1. Declaration of Human Right (1948)

2. Convention on the Rights of Persons with Disabilities (2011)

3. Global policy on education for all of the UNESCO (1994)

4. The 1945 Constitution Article 31 (1) “... that every citizen shall have equal access to education

5. Law No. 82016 about Person with Disabilities
6. Law No. 202003 on National Education System, article 4 (1) States: "education in this country is organized democratically and equally non-discriminatory and upholds human rights, religious values, cultural values and national pluralism.

7. Regulation of the Minister of National Education of the Republic of Indonesia No. 70 2009 on Inclusive Education.

The mandate of World Country Report of WHO [12], higher education as an academic institution should able to: Remove barriers to the recruitment and participation of students and staff with disabilities; Ensure that professional training courses include adequate information about disability, based on human right principles; Conduct research on the lives of persons with disabilities and on disabling barriers, in consultation with disabled people's organizations.

Inclusive education is conceptually based on the belief that all people have the right to be included in ageappropriate activities with their peers throughout life in order to maximize the potential of the children. The Global Partnership for Disability and Development (GPDD) recommends to establish a 'people bank for technical assistance' [19] to connect supply and demand for knowledge and expertise around inclusive development, and allowing user entry of data and content. Technical assistance would be complemented by a repository of intellectual output provided by disability and development partners and practitioners.

According to Forlin Inclusive Education system in as stated in UNCRPD article 24 recognizes that education should be accessible without discrimination and on the basis of equal opportunity [20].

In Indonesia the problem of disability is relatively quiet from academic and social touch. People with disabilities has not been fully seen in the social studies and discourses. Whereas, people with disabilities are significant minority group in this country. According to PUSDATIN of Ministry of Social Affair in 2010, the number of people with disabilities is $11,580,117$ with $3,474,035$ are visually impaired, 3,010,830 (physically disabled persons), 2,547,626 (hearing impairment), 1,389,614 (mental disabilities) and $1,158,012$ (chronic disabilities) [21].

The Indonesian Blind Unity (Persatuan Tuna Netra Indonesia) reported there are only 250 blind people in Indonesia who successfully completed the study at university. Ministry of Health Affair revealed that the number of blindness in Indonesia is $1.5 \%$ of the total population or more than three million people. The percentage of educational level of persons with disabilities in higher education no more than 0,95\%.[22] in addition, Rizky reported that limited access of universities for persons with disabilities makes the number of persons with disabilities who have very few undergraduate degrees [22].

Thus, here is the emergence on university commitment to implement social inclusion for people with disabilities with new approaches such as Human Rights, anti-oppression, antidiscrimination, accessibility and realization of inclusive 
society. Human rights-based practices centers on breaking down the barriers to participation and a meaningful life, countering discrimination, building confidence in people with disabilities so that they are able to advocate for themselves [18].

\section{CONCLUSION}

Disability Mainstreaming Program is indeed become strategic effort for the higher institution to prove themselves as an inclusive university. This paper concludes disability should become people awareness and become integrative agenda with the social development. The university plays important role to implement the policy on an inclusive education system. University should formulate strategic programs, approaches, as well as framework for disabilities mainstreaming and awareness.

Everyone should provide better opportunities and equal participation for the disabled persons. The struggle to fight against discrimination and social exclusion towards disabled persons should become both individual and organizational commitment at the University level.

Future research should include and more deepen to address on the implementation of disability mainstreaming program at the university level as well as to address the disable barriers in all levels.

\section{REFERENCES}

[1] C. R. . Aji Suksmo, Practices and Challenges of Inclusive Education in Indonesian Higher Education. Bangkok: ASEACCU, 2017.

[2] S. Aji and R. . Clara, Practices and Challenges of Inclusive Education in Indonesian Higher Education. Bangkok: ASEACCU, 2017.

[3] United Nations, "Convention on the Rights on Persons with Disabilities and Optional Protocol (CRPD)." 2011.

[4] R. Hasnain, L. C. Shaikh, and H. Shanawani, Disability and the Muslim Perspective: An Introduction for Rehabilitation and Health Care Providers. University at Buffalo, The State University of New
York: Center for International Research Information and Exchange (CIRRIE), 2008.

[5] JICA, Gender Mainstreaming: Inclusive and Dynamic Development. Tokyo: Mixed Source, 2011.

[6] "Republic of Indonesia Country Report on the Follow Up to the Declaration of Commitment on HIV/AIDS (UNGASS)," Indonesian National AIDS Commission, 2012.

[7] united nations, "Mainstreaming disability in the development agenda," Division for Social Policy and DEvelopment Disability, 2008.

[8] B. Morgado, D.-C. Vega, R. Lopez, E. Alfarez, and A. Morina, "Inclusive Education in Higher Education ?," Jorsen, vol. 16, no. S1, 2016.

[9] M. Oliver, Understanding Disability (From Theory to Practices. London: Macmillan Press, 1996.

[10] J. Harris and V. White, Oxford Dictionary of Social Work and Social Care. UK: Oxford University Press, 2013.

[11] (Callards, Principles and Concepts, Mental Illness Discrimination and the Law Fighting for Social Justice. 2012.

[12] World Health Organization, "World Report on Disability," The World Bank, Malta, 2011.

[13] T. Mizrahi and L. E. Davis, "Encyclopedia of Social Work." Oxford University Press, 2008.

[14] Irwanto, E. R. Kasim, A. Fransiska, M. Lusli, and O. Siradj, "Analisis Situasi Penyandang DIsabilitas di Indonesia: Sebuah Desk Review," Jakarta, 2010.

[15] Secretariat, "Follow-up to the World Summit for Social Development and the twenty-fourth special session of the General Assembly: emerging issues: 'Mainstreaming disability in the development agenda." 2008.

[16] D. Jones, L. Webster, F. SMith, N. Doyle, T. Martin, and P. Andyka, A Handbok on Mainstreaming Disability. London: VSO, 2006.

[17] "Disability mainstreaming in the new streamlined European social protection and inclusion processes," Disability High Level Group Work Programme 2006-2007 Meeting of 11 \& 12 October Agenda point 3. 2007.

[18] J. Ife, . Human Rights and Social Work: toward Rights- Based Practice. Cambridge University: Cambridge University, 2001.

[19] "Global Partnership for Disability and Development Summary of Article 32." Global Partnership for Disability and Development.

[20] C. Forlin, D. Chambers, T. Loreman, J. Deppeler, and U. Sharma, "Inclusive Education for Student with Disability," Australia, 2013.

[21] "Inklusi Penyandang Disabilitas di Indonesia," International Labour Organization (ILO), Jakarta.

[22] R. Ulfah Fatmala, "Kebijakan Kampus Inklusif bagi Penyandang DIsabilitas (Studi tentang Advokasi Kebijakan KAmpus Inklusif di Universitas Brawijaya," Repos. Univ. Brawijaya, 2012. 